\title{
'Leak' rumours fuel debate on gene patent
}

London. Two research groups potentially engaged in a priority dispute over the discovery of the second heriditary breast cancer gene, $B R C A 2$, have entered negotiations over the terms under which each may let the other look at data used in preparing patent applications that were filed only a few days apart.

The negotiations follow the announcement on 20 December by Myriad Corporation of Salt Lake City that it had filed a patent application for all the diagnostic and therapeutic uses of the gene, the day before its details were first published by researchers at the Institute of Cancer Research (ICR) in
London (see Nature 378, 789; 1995).

The British group has also applied for a patent. In addition to indicating whether the patent claims are in conflict, the British scientists may be hoping that access to Myriad's patent data will throw some light on the truth or otherwise of rumours that the US team was assisted in its search for the full $B R C A 2$ sequence by a 'leak' of critical information from one of the teams with which they were collaborating.

Such speculation is based partly on the speed with which Myriad, believed only days previously to have been investigating a number of candidate genes, said it had success-

\section{Commercial interests delay publication}

Washington. US companies that sponsor university research projects often require the scientists involved to keep results secret longer than patent procedures require, according to a survey of 210 companies published last week in the New England Journal of Medicine (NEJM 334, 377; 1996). Data on gene products, sequences and location are among the strategically valuable information withheld.

The respondents included major pharmaceutical, agricultural, chemical, bíotechnology and other companies. Led by David Blumenthal, chief of health policy research at Massachusetts General Hospital, the study found that 59 per cent of the companies funded life sciences research at US universities. Their total spending of about $\$ 1.5$ billion in 1994 represented about 11.7 per cent of all research and development funding at the universities.

More than half ( 58 per cent) of the companies said they typically require university researchers to refrain from publishing results for at least six months in order to file patent applications. By comparison, the National Institutes of Health $(\mathrm{NIH})$ has said that 30 to 60 days was a reasonable time for its researchers to be required to keep results confidential while patent applications are filed.

A slightly lower proportion (56 per cent) admitted that their universitysupported research often or sometimes generated information that was kept secret beyond the time required to file a patent. Such information included experimental methods (listed by 56 per cent of respondents), plans for future experiments ( 53 per cent), gene products ( 27 per cent), gene sequences ( 25 per cent) and gene location (12 per cent).

The study has met with mixed reactions from academic researchers.
Blumenthal says that secrecy should be "minimized", but calls it "a more or less inevitable concomitant of industryfunded research".

Some accept that corporate confidentiality requirements are reasonable, given a company's need to remain competitive. "In the real world, there are people out there trying to pick off somebody else's discovery, and that's where the problem is," says Ronald Breslow, president of the American Chemical Society who, as an organic chemist at Columbia University, has collaborated with industry.

Breslow says, for example, that when he discovered a novel anti-cancer effect of a particular compound in tissue culture, it was entirely reasonable for his industry sponsor to ask him to keep the result confidential until it had been able to test the compound for toxicity and effectiveness in animals.

But others claim that commercial secrecy requirements have increased the frequency with which researchers attending scientific meetings refuse to disclose all their information. Sheldon Krimsky, a science policy specialist at Tufts University in Medford, Massachusetts, who has studied the relationship of industry to academic science, says that the new data suggest that companies that support scientists are asking for "a lot more" than simply the protection of information to gain patents.

Others add that companies can require scientists to keep silent for as long as a decade. In an accompanying commentary to the NEJM article, Steven Rosenberg, a researcher at the National Cancer Institute, reported that one company had denied a request for a reagent after he had refused to agree not to disclose any data or results for ten years.

Meredith Wadman fully located $B R C A 2$, using the full sequence made publicly available over the Internet by the Sanger Centre in Cambridge, England and the University of Washington in St Louis (see Nature 378, 425; 1995).

Gordon McVie, director of the Cancer Research Campaign which provided much of the funding for the ICR work, says that Myriad's announcement was no surprise, as it had been working hard to find the gene. But he acknowledges that he is aware of the rumour of a leak, said by some to have centred on the crucial information that $B R C A 2$, like its companion $B R C A 1$, contains one unusually large exon.

Scientists from Myriad, whose own data are due to be published in next month's Nature Genetics - and who had already been among the favourites to find $B R C A 2$ following their earlier success in locating $B R C A 1$ - are refusing to comment on the company's announcement that it had discovered the gene and applied for a patent on it.

But Chris Taylor, a spokesman for the company, says that he "strongly disagrees" with the claim that Myriad researchers had made use of data derived from the ICR team in their discovery. Taylor points out that, while Myriad acknowledges that the ICR team, headed by Mike Stratton, was the first to publish what it calls the "partial sequence" of the gene, it was Myriad which first made the whole sequence available through GenBank.

While legal representatives of the British and US scientists investigate the degree of overlap between their patent claims - and thus weigh up whether to challenge each others' claims in court, or to seek some mutual accommodation - others have been commenting on the use by both teams of the Sanger/Washington University data.

Some are concerned, for example, that Myriad's substantial investment in gene sequencing and other analytical equipment has placed it in a much stronger position to make use of such 'public' data compared to smaller, less well-resourced groups.

"I am worried that anyone who asks one of these 'public' data banks in future to sequence a human gene may, as a result of such a policy, immediately find the information produced being patented by a large pharmaceutical or gene sequencing company," says one scientist, adding that in future he intends to keep all his own sequence information private until it is protected.

But David Bentley of the Sanger Centre defends the decision to go public with the full sequence within which the $B R C A 2$ gene was later found by both the ICR and Myriad teams. "If we hide this data, we will not be allowing the maximum number of people to use it as they can, and we will be deciding who should have access to it," he says.

David Dickson 